\title{
GERAKAN PETTA BARANG DI DAERAH BUGIS PADA 1906-1913
}

\section{PETTA BARANG MOVEMENT IN THE BUGIS IN 1906-1913}

\author{
Muhammad Amir \\ Balai Pelestarian Nilai Budaya Makassar \\ Jalan Sultan Alauddin - Talasalapang Km 7 Makassar, 90221 \\ Telepon (0411) 885119,883748, Fax (0411) 865166, HP 081344797300 \\ Email: muhabpnb@yahoo.co.id
}

Naskah diterima tanggal 4 Oktober 2017. Naskah direvisi 18 Oktober 2017. Naskah disetujui 30 Oktober 2017.

\begin{abstract}
Abstrak
Kajian ini bertujuan menguraikan gerakan perlawanan Petta Barang terhadap pemerintah Belanda di daerah Bugis. Metode yang digunakan adalah metode sejarah, yang menjelaskan suatu persoalan berdasakan perspektif sejarah. Prosedur kerjanya terdiri atas heuristik, kritik sumber, interpretasi, dan historiografi. Hasil kajian menunjukkan, pendudukan militer Belanda dan mengambilan kekuasaan pemerintahan atas Kerajaan Bone oleh pemerintah kolonial Belanda menjadi latar belakang munculnya gerakan Petta Barang. Ia memulai gerakannya sebagai seorang dukun yang sakti dan "menjual" atau membagikan jimat kepada pasien atau penduduk yang bersedia menjadi pengikutnya. Oleh karena itu, nama dan kesaktian Petta Barang semakin terkenal di masayarakat serta pengaruhnya pun semakin luas, baik di daerah Bone pada khususnya maupun di daerah Bugis pada umumnya. Setelah kedudukannya cukup kuat, Petta Barang memerintahkan kepada para pengikutnya untuk melancarkan serangan terhadap kedudukan pasukan Belanda di Watampone, Pattiro Bulu, dan sejumlah tempat di daerah Bugis. Selain itu, juga melakukan penyerangan terhadap pasukan patroli Belanda pada setiap ada kesempatan, sehingga cukup merepotkan pasukan Belanda. Itulah sebabnya, pemerintah Belanda memusatkan perhatian dan mengerahkan kekuatan militer untuk menumpas gerakan Petta Barang bersama para pengikutnya. Usaha-uasaha itu akhirnya membuahkan hasil ketika Petta Barang berhasil ditangkap di Citta, Soppeng pada 1913.
\end{abstract}

Kata kunci: Petta Barang, gerakan, Kerajaan Bone, Belanda.

\begin{abstract}
This study aims to reveal and explain the movement of Petta Barang against the Dutch government in the Bugis region. The method used is the historical method, which explains a problem based on historical perspective. The work procedure consists of heuristics, source criticism, interpretation, and historiography. The results of the study show that the Dutch military occupation and take the power of government over the Kingdom of Bone by the Dutch colonial government became the background of the Petta Barang movement. He began his movement as a magic shaman and "sold" or distributed amulets to patients or the people who wished to be his followers. Therefore, the name and the magical power of Petta Barang became more popular in the society as well as his popularity increasingly widespread, both in Bone area in particular and in the Bugis region in general. Having had strong position, Petta Barang ordered his followers to launch an attack on the position of Dutch troops in Watampone, Pattiro Bulu, and some places in the Bugis area. In addition to that, he also attacked the Dutch patrol troops at every opportunity, so quite troublesome Dutch troops. That is why the Dutch government concentrated and mobilized the military power to quell the Petta Barang movement with his followers. The Dutch troops finally succeded following the caught of Petta Barang in Citta, Soppeng in 1913.
\end{abstract}

Keywords: Petta Barang, movement, Kingdom of Bone, and The Dutch

\section{PENDAHULUAN}

$\mathrm{P}$ enataan kedudukan kekuasaan pemerintah Hindia Belanda di Bone seusai perang tahun 1905 , tidak berjalan sebagaimana yang mereka harapkan. Sebab, meskipun Raja Bone La Pawawoi Karaeng Segeri telah diasingkan ke Bandung dan sejumlah bangsawan tinggi telah gugur di medan perang atau ditangkap oleh pasukan Belanda tidak 
berarti bahwa perlawanan terhadap pemerintah kolonial Belanda telah berakhir. Salah satu di antaranya adalah munculnya gerakan Petta Barang pada 1906. Gerakan yang dipimpin oleh Petta Barang ini, bukan hanya dimaksudkan untuk menentang kedudukan kekuasaan pemerintah Hindia Belanda, melainkan juga bertujuan memulihkan kembali kedudukan kekuasaan Kerajaan Bone. Penghapusan sistem pemerintahan kerajaan dan pelaksanaan sistem pemerintahan kolonia Belanda, telah menghilang kedudukan kekuasaan dan mengurangi sumber pendapatan sejumlah bangsawan (Caron, 1933: 43; Poelinggomang, 2004: 156). Itulah sebabnya mereka mengorganisir kekuatan untuk menentang kekuasaan pemerintah Belanda.

Gerakan yang dipimpin oleh Petta Barang, berawal ketika ia bersama para pengikutnya melancarkan serangan terhadap pasukan Belanda di Watampone pada Juli 1906. Meskipun tidak memiliki persenjataan yang baik seperti senapan atau senjata api lainnya, namun keberanian para pengikutnya dalam serangan itu dan seranganserangan berikutnya menimbulkan kekhawatiran dan ketakutan bagi pasukan Belanda. Sebab hanya bersenjatakan tombak dan keris, mereka tidak gentar dan tidak takut melancarkan serangan terhadap pasukan Belanda. Bahkan sebagian pengikutnya hanya bermodalkan jimat yang diberikan Petta Barang dan senjata seadanya berani menyerang pasukan Belanda sedang melakukan patroli. Petta Barang tidak hanya mempunyai pengikut di Bone, tetapi juga di sejumlah daerah di Sulawesi Selatan, misalnya di Soppeng, Barru, Tanete, Segeri, Camba, dan Sinjai. Oleh karena itu, pasukan Belanda cukup mengalami kesulitan untuk menumpas gerakan itu karena mendapat dukungan dari masyarakat Sulawesi Selatan, khususnya di daerah Bugis (Poelinggomang \& Muh. Arfah,1995: 3).

Persoalan pokok yang akan diuraikan dalam kajian ini adalah mengapa Petta Barang melakukan gerakan perlawanan terhadap pemerintah Hindia Belanda. Hal ini tidak hanya diarahkan untuk memahami latar belakang munculnya gerakan Petta Barang,tetapijuga bertujuan memberikan penjelasan menyangkut pasang surut gerakan perlawanan tersebut. Persoalan yang mendasari munculnya gerakan Petta Barang, terutama perkembangan politik baik menjelang maupun pasca penaklukan Kerajaan Bone, perlu mendapat perhatian dan tidak dapat diabaikan dalam memahami latar belakang gerakan itu. Sebab hal itu, tidak hanya menyangkut faktor penyebab munculnya gerakan Petta Barang, tetapi juga merupakan kondisional yang melapangkan munculnya ketidakpuasan rakyat. Demikian dinamika gerakan perlawanan itu, mulai dari awal hingga akhir perlawanan menunjukkan bahwa pemerintah Hindia Belanda tidak mudah dan cukup lama dalam menumpas gerakan Petta Barang bersama para pengikutnya. Untuk memperoleh gambaran yang utuh tentang gerakan itu, tentu harus didukung oleh ketersidaan sumber-sumber sejarah baik tertulis maupun tidak tertulis.

\section{Tinjuan Pustaka}

Sesungguhnya terdapat sejumlah studi mengenai gerakan sosial di Sulawesi Selatan yang dapat memberi inspirasi dalam memahami gerakan Petta Barang. Salah satunya adalah studi Mukhlis PaEni (2002), tentang Batara Gowa messianisme dalam gerakan sosial di Makassar (2002). Menurutnya, perubahan sosial akibat pengaruh Barat (Belanda) yang semakin kuat kedudukannya di Makassar, bukan hanya mengakibatkan terjadinya keresahan sosial di masyarakat, melainkan juga menjadi penyebab munculnya gerakan perlawanan. Studi lainnya adalah Gerakan DI/TII (Darul Islam/Tentara Islam Indonesia) di Sulawesi Selatan oleh Barbara Sillars Harvey (1989). Studi ini berusaha memberikan gambaran tentang tradisi masyarakat Sulawesi Selatan dalam kerangka Gerakan DI/TII. Gambaran yang tidak jauh berbeda ditunjukkan oleh Anhar Gonggong (1992) yang mengkaji tentang gerakan Kahar Mudzakkar, bahwa latar belakang munculnya gerakan itu bukan hanya karena faktor politik, militer, dan ideologi, melainkan juga faktor budaya (siri dan pesse) yang muncul akibat kekecewaan para pemimpin gerilya terhadap pemerintah Republik Indonesia. Selain itu, studi Edward L. Poelinggomang (2004) tentang perubahan politik dan hubungan kekuasaan di Makassar, menunjukkan bahwa gerakan-gerakan sosial merupakan bentuk protes terhadap dominasi pemerintah kolonial Belanda. Lain halnya Taufik Ahmad yang mengkaji bandit dan pejuang di Polongbangkeng (2014), menunjukkan, gerakan bandit diwarnai oleh aksi-aksi kekerasan berjalan seiring dengan perkembangan politik, ekonomi, dan pergeseran elite dalam konteks yang luas. Sementara uraian singkat tentang gerakan Petta Barang, terdapat pada laporan serah terima jabatan aparat pemerintah kolonial Belanda, di antaranya Memori van Overgave $(\mathrm{MvO})$ dari $\mathrm{H}$. N. 
A. Swart (September 1906-April 1908), Memori van Overgave $(\mathrm{MvO})$ dari A. J. Baron Quarles de Quarles (Mei 1908-Agustus 1910), dan Memori van Overgave $(\mathrm{MvO})$ dari W. J. Coenen (Oktober 1910-Agustus 1913). Laporan dan studi tersebut, tidak hanya memberi inspirasi dan pemahaman tentang gerakan Petta Barang, tetapi juga. menjadi rujukan dalam kajian ini.

\section{METODE PENELITIAN}

Kajian ini menggunakan metode sejarah yang terdiri atas heuristik (pencarian dan pengumpulan sumber), kritik (analisa sumber); interpretasi (penafsiran); dan merekonstruksi dalam bentuk narasi sejarah atau historiografi (Notosusanto, 1978: 17; Gottschalk, 1986: 34). Pengumpulan sumber berupa arsip atau dokumen-dokumen pemerintah kolonial Belanda dilakukan pada lembaga kearsipan, terutama di Badan Arsip dan Perpustakaan Provinsi Sulawesi Selatan di Makasar dan Arsip Nasional Republik Indonesia di Jakarta. Selain itu, juga dilakukan pengumpulan sumber pustaka berupa buku, artikel, laporan penelitian, dan sumber tertulis lainnya yang berkaitan dengan gerakan Petta Barang. Untuk melengkapi sumber tertulis, kajian ini juga menggunakan sumber lisan berupa hasil wawancara dengan tokoh-tokoh masyarakat yang dapat memberikan informasi tentang gerakan Petta Barang. Setelah sumber terkumpul dilakukan analisis melalui tahapan kritik sumber untuk memastikan otentitas dan validitas sehingga menjadi suatu fakta. Selanjutnya faktafakta yang telah diperoleh diinterpretasi kemudian direkonstruksi menjadi narasi sejarah tentang gerakan Petta Barang.

\section{PEMBAHASAN}

\section{Latar Belakang Gerakan}

Pemerintah Hindia Belanda bergiat memperluas wilayah kekuasaannya di Sulawesi Selatan pada awal ke-20. Usaha perluasan wilayah kekuasaan tersebut, bukan hanya bertujuan menguasai daerah-daerah potensial bagi usaha pertanian, perkebunan, dan pertambangan dalam rangka perluasan penanaman modal swasta Belanda di Sulawesi Selatan. Tetapi juga dimaksudkan untuk menciptakan ketertiban dan ketentraman guna menjamin keberhasilan usaha penanaman modal swasta Belanda tersebut. Selain itu, juga dimaksudkan untuk mencegah pengaruh politik bangsa asing lainnya pada kerajaan-kerajaan di Sulawesi Selatan, termasuk Kerajaan Bone (Kadir,dkk.1984: 45; Abduh, dkk.1985: 96).
Selain itu, pemerintah Belanda jugabermaksud untuk menguasai sejumlah pelabuhan, termasuk Pelabuhan Bajoe dan Pallime di Bone. Hal itu tidak terlepas dari rencana Belanda untuk melaksanakan kebijakan pelabuhan wajib pajak. Rencana itu mulai tampak ketika pemerintah Belanda di Makassar pada 1900, menyebabkan informasi kepada kerajaan-kerajaan di Sulawesi Selatan, bahwa kebijakan pelabuhan bebas akan dihapuskan, dan kepada mereka akan diberikan uang ganti rugi atas pungutan-pungutan pajak impor-ekspor, cukai, pajak pelabuhan, pajak jangkar, dan ketentuanketentuan lain yang menyangkut pelayaran dan perdagangan. Ganti rugi tersebut, pada dasarnya merupakan langkah politik untuk menegaskan bahwa kerajaan-kerajaan di Sulawesi Selatan berada di bawah kekuasaan Belanda (Poelinggomang,2002: 90; Tol, 2009: 169).

Kebijakan pemerintah Belanda itu, mendapat penolakan dari kerajaan-kerajaan yang berdaulat di Sulawesi Selatan karena akan melenyapkan sumber pendapatan dan wilayah kekuasaan mereka, termasuk Bone. Kendatipun gubernur Sulawesi yang menginformasikan rencana kebijakan itu dengan berkunjung langsung ke Bone. Kemudian masih dijelaskan lagi oleh residen Belanda yang ditempatkan di Bone (Surat Gubernur pada 19 Maret 1900). Sikap kerajaan-kerajaan di Sulawesi Selatan, khususnya Bone itulah yang antara lain menyebabkan penghapusan kebijakan pelabuhan bebas dan pelaksanaan kebijakan pelabuhan wajib pajak tertunda (Polinggomang, 2002: 90-91). ${ }^{1}$

1 Sebab-sebab lain tertundanya pelaksanaan wajib pajak di Makassar: Pertama, menurut hasil penelitian Vermeulen (1896) dan laporan Gubernur Sulawesi Gerrit W.W.C. Baron van Hoevell (1898-1903) pada 1900, bahwa penduduk Sulawesi Selatan memegang peran penting dalam kegiatan niaga di wilayah Kepulauan Hindia-Belanda bagian timur. Kedua laporan ini menyebabkan pemerintah meragukan keterangan bahwa kebijakan pelabuhan wajib pajak hanya akan mengurangi volume perdagangan di Makassar sebesar 22 persen. Kedua, kerajaan-kerajaan bumiputra dapat memblokade pelayaran penduduk ke bandar niaga pemerintah. Ketiga, diperkirakan pendapatan dari kerajaan-kerajaan bumiputra tidak dapat terpenuhi. Keempat, kerajaankerajaan bumiputra dapat mengembangkan bandar niaga mereka untuk bersaing dengan bandar niaga pemerintah sehingga muncul perdagangan gelap. Kelima, kerajaankerajaan bumiputra dapat meningkatkan hubungan politik dan ekonomi dengan negara asing sehingga mengancam kedudukan politik dan ekonomi pemerintah. 
Dalam rangka perluasan wilayah kekuasaannya di Sulawesi Selatan, pemerintah Belanda berkesimpulan bahwa satu-satunya pemecahan terhadap pembangkangan Bone ialah penaklukan secara militer yang secara halus disebut pacificatie politiek (Harvey,1989: 46). Usaha perluasan wilayah kekuasaan melalui penaklukan militer, mencapai puncaknya pada masa pemerintahan Gubernur Jenderal J.B.van Heutsz (1904-1909). Ketika Van Heutsz tampil menggantikan W. Roosemboom sebagai Gubernur Jenderal Hindia Belanda pada 1 Oktober 1904, ia mulai mencanangkan suatu kebijakan baru ke arah penguasaan daerah jajahan yang lebih intensif, dengan tujuan pokok ialah menguasai secara langsung seluruh wilayah Hindia Belanda, supaya terhindar dari kemungkinan campur tangan bangsa asing lainnya (Poelinggomang, 2002: 91; Kadir,dkk.1984: 45).

Berdasarkan kebijaksanaan itu, Gubernur Sulawesi Kroesen, mengajukan usul kepada Van Heutsz pada April 1905, agar dilakukan tindakan penaklukan terhadap seluruh Sulawesi Selatan, terutama terhadap Bone dan Gowa. Usul dari Kroesen itu, akhirnya mendapat persetujuan dari pemerintah Belanda. Hal ini jelas dinyatakan dalam surat resmi yang dikirimkan kepada gubernur Sulawesi pada 14 Juni 1905. Pada intinya, isi surat tersebut merupakan perintah kepada Kroesen, agar memaksa raja-raja di Sulawesi Selatan untuk menyerahkan kekuasaan, yaitu tunduk, patuh, dan taat sepenuhnya kepada pemerintah dengan menandatangani korte verklaring (Harvey, 1989: 48; Poelinggomang, 2002: 92). ${ }^{2}$

Sementara itu, pemerintah Belanda mempersiapkan suatu ekspedisi militer untuk melaksanakan penaklukan, apabila raja-raja di Sulawesi Selatan menolak menandatangani korte verklaring (pernyataan pendek). Tindakan penaklukan yang pertama dilakukan terhadap Bone, karena dianggap sebagai "kerajaan yang paling kuat dan bernahaya". Gubernur Kroesen setuju bahwa Bone adalah paling berbahaya di antara kerajaan-kerajaan di Sulawesi Selatan.

2 Rumusan korte verklaring ini dipengaruhi oleh perubahan kebijakan politik pemerintah Belanda berdasarkan Pidato Takhta (Troon Rede) Ratu Belanda pada 1901. Pidato Tahta inilah yang menjadi landasan Politik Etis di Hindia Belanda sekaligus pernyataan diplomatis untuk mem-benarkan penguasaan terhadap kerajaan-kerajaan bumiputra.
Di samping itu, juga karena "sikapnya yang kurang ajar", yaitu berani menolak tuntutan pemerintah yang hendak menguasai pelabuhan Bajoe dan Pallime. Menurut Kroesen bahwa demi menegakkan dan mempertahankan kewibawaan pemerintah, melaksanakan perubahan yang diperlukan dalam hubungan dengan para penguasa lokal, serta persetujuan terhadap tuntutan-tuntutan pemerintah harus dipaksakan, kalau perlu dengan kekerasan (Kroesen, 1906: 10; Harvey,1989: 49).

Namun Van Heutsz memperingatkan, harus bersikap hati-hati agar tidak memancing timbulnya perlawanan dan menghindari kesan bahwa pemerintah hanya mencari-cari alasan untuk menguasai Bone. Karena itu berangkatlah suatu rombongan ke Bone pada 21 Juni 1905, untuk menyampaikan surat kepada raja Bone. Rombongan itu terdiri atas Brugman, Goedhart, Cramer yang tiba di Bajoe pada 22 Juni 1905 (Anonim,1915: Lamp: 3). Dengan dua buah kapal perang berjagajaga di lepas pantai, mereka mengirim utusan (Karaeng Maros dan Kapitan Melayu) untuk menyampaikan surat, yang isinya menuntut Bone agar bekerjasama dengan pemerintah Belanda, dalam hal penarikan pajak impor dan ekspor, serta penempatan pejabat Belanda di Bone untuk melaksanakan pemerintahan guna mengatur dan mengawasi pelabuhan. Setelah surat itu dibaca dan dipertimbangkan, disampaikanlah surat balasan penolakan tuntutan itu pada 29 Juni 1905 (Anonim,1905-1906: 274; Amir, 2003: 63; Abduh dkk.,1985: 100).

Penolakan Bone atas tuntutan itu, mendorong pemerintah Belanda segera memberangkatan ekspedisi militernya ke Sulawesi Selatan (Anonim,1915: 26; Poelinggomang, 1980: 59; Kadir, dkk. 1984: 46). ${ }^{3}$ Pada 18 Juli 1905, ekspedisi yang terdiri atas $25 \mathrm{kapal}$ (perang dan pengakut pasukan) tiba di BajoE dan berlabuh pada jarak sekitar 5.000 meter dari pantai (Patang,1976: 24; Patunru, 1989: 277). ${ }^{4}$ Pimpinan ekspedisi lalu mengutus La

3 Pasukan dari Jawa Barat diberangkatkan dari Tanjung Priok pada 11 dan 13 Juli 1905, dan pasukan dari Jawa Tengah diberangkatkan dari Semarang pada 13 dan 15 Juli 1905, serta pasukan dari Jawa Timur diberangkatkan dari Surabaya pada 13 dan 15 Juli 1905. Semua armada pasukan yang diberangkatkan itu, berlayar menuju suatu tempat yang telah ditentukan, yaitu harus berkumpul di Pelabuhan Bulukumba. Kemudian, dari Bulukumba mereka meneruskan pelayaran menuju BajoE, sebuah pelabuhan yang terletak di Teluk Bone.

4 Kapal-kapal perang dan pengangkut itu, antara lain; 
Patola untuk menyampaikan ultimatun terakhir kepada raja Bone, yaitu agar bersedia menerima segala tuntutan dalam waktu 2x24 jam (Anonim, 1905: 353; Anonim,1915: 30). ${ }^{5}$ Raja Bone lalu menyampaikan kepada perutusan Belanda, bahwa sesuai dengan adat kebiasaan yang berlaku di Bone, baik untuk kepentingan raja maupun untuk kepentingan rakyat, tidak ditentukan oleh raja sendiri. Melainkan harus melalui musyawarah yang disepakati oleh dewan Ade Pitu Bone (Ali, 1984: 14; Amir, 2003: 87).

Pada 20 Juli 1905, raja Bone menyampaikan jawaban penolakan, bahwa semua usaha untuk membawa Bone kepada pemikiran yang lebih baik haruslah dipandang tidak bermanfaat (Kielstra,1910: 362; Kadir,1984: 48). ${ }^{6}$ Penolakan Bone itu merupakan isyarat bagi pimpinan ekspedisi untuk melakukan penyerangan. Pada hari itu, pasukan Belanda mulai melakukan pendaratan di Ujung Pattiro tanpa mendapat perlawanan yang berarti. Menyusul pendaratan di Bajoe pada 27 dan 28 Juli 1905, yang disertai dengan tembakan-tembakan meriam dari kapal-kapal perang Belanda. Meskipun laskar Bone memberikan perlawanan atas serangan itu, namun pasukan Belanda berhasil menduduki

Riemsdijk, De Goen, Bromo, H. N. Hertog, Hendrik, Koningin, Regentes, De Ruyter, Soeland, Borneo, Asahan, Serdang, Brak, Tjantik II, dan Argus. Pasukan ekspedisi itu, pada mulanya di bawah pimpinan oleh Kolonel Infantri Van der Wedden sebagai Panglima Operasi, dan Kolonel Infantri C. A. van Loenen sebagai Wakil Panglima Operasi, serta Kolonel Kaveleri Jhr. L. D. C. de Lannoy sebagai Panglima Tempur. Berhubung karena Kolonel Van der Wedden sakit, maka ia kemudian digantikan oleh Kolonel Van Loenen sebagai Panglima Operasi.

5 Dalam sumber lain disebutkan bahwa isi pokok tuntutan itu adalah Bone harus menandatangani ketentuan penyerahan kekuasaan kepada pemerintah Belanda, persetujuan ganti rugi, pelaksanaan penarikan pajak atas ekspor dan impor, mengakui hak pemerintah Belanda dalam daerah Bone. Sehubungan dengan itu, maka pegawai pemerintah Belanda akan ditempatkan di Bone (Kielstra, 1910: 362).

6 Sementara sumber lain menyebutkan, Arumpone menyatakan bahwa dia tidak bermaksud melawan pemerintah, tetapi tuntutan yang diajukan terlalu berat. Mengenai permintaan konpensasi keuangan yang harus diberikan oleh Bone kepada Belanda, Arumpone menulis "Sekalipun orang menjual seluruh penduduk Bone, hasilnya saya kira tidak akan cukup untuk membayar jumlah yang telah ditetapkan Jenderal"(Anonim,1915: Lamp.XII; Tol,2009: 175).
Bajoe dan sekitarnya pada 29 Juli, Watampone (30 Juli), Palakka (31 Juli), dan Pasempe (2 Agustus) 1905 (Anonim, 1905: 353-357; Ali,1984: 18-23; Anonim, 1915: 43; Tol, 2009: 178).

Kekalahan itu memaksa raja Bone keluar dari wilayah kekuasaannya dan menjalin kerjasama dengan kerajaan lain untuk melawan pasukan Belanda. Setelah kurang lebih empat bulan (Agustus-November) raja Bone bersama pasukannya melakukan perlawan gerilya, keluar masuk hutan, naik turun gugung, berpindah dari tempat ke tempat lainnya, akhirnya terjadilah pertempuran di Pegunungan Awo, Tanah Toraja pada 18 Novemver 1905. Pada pertempuran itu, Petta Ponggawae Abdul Hamid bersama puluhan pimpinan laskar Bone gugur sebagai kusuma bangsa. Sementara raja Bone berhasil ditangkap dan ditawan oleh pasukan Belanda. Kemudian dengan alasan demi keamanan dan ketertiban, raja Bone diasingkan oleh pemerintah Belanda ke Bandung pada 14 Desember 1905 (Abduh,1985: 109; Patunru, 1989: 285; Amir, 2003: 115).

\section{Asal Mula Gerakan Petta Barang}

Gugurnya Petta Ponggawae Adul Hamid di Pegunungan Awo dan pengasingan Raja Bone La Pawawoi Karaeng Segeri ke Bandung, tidak berarti bahwa perlawanan Bone terhadap Belanda telah berakhir. Sebab tidak lama setelah Bone diduduki dan dikuasai Belanda, timbul gerakan perlawanan yang dipimpin oleh Petta Barang. Siapa sesungguhnya Petta Barang atau Daeng Pabarang, ${ }^{7}$ belum dapat dipastikan. Sumber tertulis dan keterangan lisan yang berhasil dikumpulkan, belum dapat memastikan asal-usulnya. Oleh karena riwayat tentang asal-usul tokoh itu lebih bersifat mitos. Ia dikisahkan hadir ke dunia ini tidak seperti manusia biasa, tetapi diturunkan dari langit (Tomanurung). Keterangan itu diperoleh W.J. Coenen, ketika melakukan percakapan dengan Petta Barang sebelum diasingkan ke Jawa. Dari percakapan itu terungkap pula bahwa, Petta Barang sangat bangga mendapat penghormatan dalam lingkungannya. Dahulu ia senantiasa berada dalam lingkungan istana. Ketika berada di Bikeru pada masa mudanya, ia dianugerahi sebuah keris bersarung emas oleh salah seorang pengikutnya (Coenen,1913: MvO).

7 Nama pemimpin gerakan itu dalam sumber arsip pemerintah kolonial Belanda disebut Daeng Pabarang, sedang di kalangan orang Bone dikenal dengan sebutan Petta Barang. 
Keterangan yang diungkapkan oleh Coenen tersebut, berbeda dengan riwayat yang berkembang dalam masyarakat. Terdapat riwayat yang mengisahkan bahwa ketika Petta Mangung mengakhiri pertapaannya di Gunung Bawakaraeng, ia menemukan seorang tua sedang bersandar pada sebuah pohon. Ia kemudian mendekati orang tua itu dan mengajaknya ke Pasempe. Tiba-tiba mereka melihat dua ekor kuda berada dekatnya, seekor berwarna hitam dan yang lainnya berwarna putih. Mereka menggunakan kuda itu berangkat menuju Pasempe. Petta Mangung mengantar orang tua itu ke kediaman Arung Pasempe Parakassi Petta Siga, ${ }^{8}$ untuk memperkenalkan dan melaporkan kehadiran orang tua itu. Pada waktu Arung Pasempe menanyakan identitas orang tua itu, ia hanya membisu dan tidak menjawab pertanyaanpertanyaan menyangkut identitasnya. Orang tua itu hanya bermohon kiranya ia ditempatkan di atas loteng rumah (rakkeang) dari Arung Pasempe. Permohonan itu dikabulkan dan di tempat itu ia duduk, makan, dan istirahat. Sebagai tamu, orang tua itu dilayani dan disajikan makanan menurut tata cara kebangsawanan (Transkrip No. 19). ${ }^{9}$

Selain itu, terdapat pula riwayat tentang Petta Barang yang meng-hubungkan asal usulnya dengan keluarga Raja Bone Arung Timurung (1871-1896). Diriwayatkan, Petta Barang adalah putra dari perkawinan antara Arung Timurung dengan Karaeng Popo (putra Raja Gowa Karaeng Katangka). Putra itu meninggal ketika masih kecil. Konon kabarnya setelah tiga hari dimakamkan, ia bangkit dan hidup kembali. Ia kemudian kembali ke istana untuk menemui ibunya. Namun ibunya tidak percaya dan menolak anak itu hidup di istana. Penolakan ibunya itu menyebabkan sang anak meninggalkan Bone menuju Belawa. Dari sana ia meninggalkan Sulawesi menuju Jawa dan menetap di Gresik.Ketika ia telah dewasa, tiba-

8 Petta Mangung adalah ipar dari Arung Passempe Parakassi Petta Siga, karena Parakassi Petta Siga mengawini saudara perempuan Petta Mangung yang bernama I Kumala Petta Tenne.

9 Namun tata cara pelayanan tersebut ditolak oleh Petta Barang. Ia tidak menyenangi bila setiap jenis makanan dan lauk disajikan terpisah, masing-masing pada piring tersendiri. Ia menghendaki agar seluruh jenis makanan dan lauk yang disajikan itu disatukan dalam satu tempat apa saja (sembarang). Sikap dan keinginan itulah yang mendasari pertimbangan Arung Pasempe menamakan orang tua itu dengan Petta Barang, sebuah nama yang memiliki arti "sembarang". tiba muncul kembali di Pasempe dan melakukan kegiatan sebagai seorang dukun (sanro) yang sakti, memiliki kekuatan magis, dan menguasai kekuatan supernatural (Transkrip No.2; Poelinggomang \& Muh. Arfah,1995: 45).

Gubernur Sulawesi H. N. A. Swart melaporkan bahwa Petta Barang menampakkan diri sebagai seorang putra dari Raja Bone Basse Kajuara (18571860). Ia harus berjuang terus menerus tanpa mengenal lelah dan tidak boleh berhenti sebelum ia jatuh ke tangan pemerintah baik dalam keadaan hidup ataupun mati (Swart,1908: MvO). Sementara dalam laporan serah terima jabatan (memorie van overgave) dari Gubernur Sulawesi, A.J.L. Couvreur diceritakan bahwa Petta Barang, seorang pemimpin gerakan kerohanian yang memulai kegiatannya sebagai dukun (sanro). Ia berlagak seperti Pamadeng Rukka, putra dari Raja Bone Basse Kajuara yang gugur di BajoE ketika pemerintah Belanda melancarkan serangan militer ke Bone pada 1860. Ia menunjukkan dirinya sebagai saudara laki-laki dari We Tenripada, istri dari Raja Gowa Sultan Husain (1895-1905). Setelah ia bertemu secara kebetulan dengan seorang wanita tua dari Wajo, yaitu ibu susu dari Pamadeng Rukkayang mengingatkan kembali luka-luka yang diderita hingga ia meninggal (Couvreur, 1929: MvO). ${ }^{10}$

Jika diperhatikan riwayat tentang Petta Barang dan mengabaikan keterangan yang diberikan oleh Gubernur Sulawesi (Swart dan Couvreur), maka dapat katakan bahwa Petta Barang adalah bangsawan istana. Keris bersarung emas yang dianugerahkan kepadanya menunjukkan bahwa benda yang diperoleh itu adalah benda kerajaan, karena kerajaan saja yang memiliki keris barsarung emas. Demikian pula jika dihubungkan dengan kehadiran Petta Mangung yang membawa tokoh itu ke Pasempe, maka dapat dikatakan bahwa keris itu dianugerahkan oleh Petta Manggung, orang yang dikatakan sebagai salah seorang pengikutnya. Penganugerahan keris itu yang menyebabkan ia bersedia kembali ke Bone bersama Petta Mangung. Mereka ke Pasempe, karena Watampone telah dikuasai Belanda. Pasempe merupakan pilihan karena tempat itu, bukan hanya lebih aman dan strategis sebagai tempat persembunyian, melainkan

10 Keterangan yang diungkapkan oleh Gubernur Couvreur itu didasarkan atas data yang diperoleh dari surat resmi Gubernur A.J. Baron Quarles de Quarles (1908-1910) kepada Gubernur Hindia Belanda tertanggal 6 Maret 1909. 
juga penguasa dan penduduk daerah itu merupakan pendukung setia raja-raja Bone. Itulah sebabnya Pasempe selalu dijadikan sebagai tempat pertahanan dan pengungsian raja-raja Bone(Nabba,2006: 117; Mappangara,1996: 198; Amir,2003: 100). ${ }^{11}$

Kehadiran Petta Barang di Pasempe memiliki arti yang penting bagi munculnya gerakan perlawanan terhadap pemerintah Belanda di Bone setelah ekspedisi militer 1905. Petta Barang memulai kegiatannya sebagai seorang dukun. Selain praktek perdukunan, ia juga membagikan dan menjual jimat kepada mereka yang datang kepadanya. Jimat itu dikatakan memiliki kekuatan magis yang dapat menyelamatkan pemakainya dari bahaya dan menjadikan pemakainya kebal terhadap senjata. Melalui praktek perdukunan dan penjualan jimat, Petta Barang mengorganisasikan kekuatan untuk melawan Belanda di Bone. Setiap orang yang datang kepadanya untuk berobat atau membeli jimatnya, Petta Barang memperkenalkan diri sebagai seorang utusan para dewa. Ia hadir ke dunia tidak seperti manusia biasa, ia diturunkan dari langit dan memiliki kekuatan berkat cahaya kesucian dari yang maha suci dan maha ajaib yang mengitarinya (Coenen, 1913: MvO).

Pernyataan tersebut menunjukkan, Petta Barang diutus ke dunia ini untuk memimpin rakyat dan memulihkan keamanan dan ketertiban demi terwujudnya masyarakat yang damai dan sejahtera. Selain itu, kehadiranya pada waktu Bone sudah tidak lagi diperintah oleh keturunan Tomanurung, peletak dasar terbentuknya kerajaan, memberi arti bahwa ia datang untuk memimpin rakyat mengusir pemerintah Belanda dan mengembalikan kedudukan kekuasaan Kerajaan Bone. Pernyataan diri sebagai bukan manusia biasa menyebabkan dalam waktu singkat, ia berhasil mengumpulkan pengikut dalam jumlah banyak dan dengan mudah pengaruhnya tersebar luas. Pengaruhnya tidak hanya dikenal dalam kalangan rakyat biasa, tetapi juga dalam kalangan bangsawan tinggi. Bahkan menurut Coenen, bahwa orang yang tidak pernah melihatnya juga memandangnya sebagai pribadi

11 Sepanjang sejarahnya, Bone baru dapat dikalahkan setelah benteng pertahanan di Pasempe berhasil dikuasai oleh musuhnya. Faktanya Gowa dapat menaklukkan Bone setelah kekalahan di Pasempe (rumpaqna Pasempe) pada 1643, Raja Bone Pancai Tana Basse Kajuara mengungsi ke Passempe dan mengalami kekalahan di tempat itu pada waktu ekspedisi militer Belanda tahun 1860. Demikian juga Raja Bone La Pawawoi Karaeng Segeri, pada waktu ekspedisi militer Belanda tahun 1905. yang mistik (Poelinggomang \& Muh. Arfah, 1995: 56).

Banyak bangsawan yang bekerjasama dan membantu Petta Barang. Putra Ratu Tanete, La Tenri Sessu, yang turut membantu pasukan Belanda pada 1905, ternyata kemudian bekerjasama dan membantu Petta Barang. Orang-orang di Soppeng pada umumnya mengenal Petta Barang dan mendukungnya. Bahkan regent Sigeri menggabungkan diri secara diam-diam dengannya dan mengirimkan bantuan uang kepada Petta Barang. Dukungan dan bantuan yang diperoleh dari para bangsawan tinggi yang mendasari pernyataan Swart bahwa semakin bertambahnya pengikut dan semakin luas pengaruhnya, bukan hanya karena perjuangannya dalam menentang pemerintahan Belanda, melainkan yang terpenting adalah jaminan pemondokan dan pangan yang disediakan bagi pengikutnya (Swart,1908: MvO; Poelinggomang \& Muh. Arfah,1995: 57).

\section{Penyerangan Watampone dan Pattiro Bulu}

Kegiatan Petta Barang di Pasempe dalam mengorganisir kekuatan perlawanan, tidak diketahui dan tidak disadari pemerintah Belanda di Bone. Hal itu bukan saja karena cara yang digunakan adalah melalui praktek perdukunan dengan sistem pengobatan tradisional, tetapi juga karena perhatian dari pasukan Belanda diarahkan untuk menaklukkan kerajaan-kerajaan di Sulawesi Selatan. Para penguasa lokal harus menyerahkan kekuasaannya dan mengakui kedudukan kekuasaan pemerintah Belanda. Daerah-daerah yang telah diduduki dan dikuasai, terutama setelah pemerintah lokal menyerahkan kekuasaannya dan mengakui kedudukan kekuasaan pemerintah, ditempatkan satu regu pasukan pada kota pusat pemerintahan yang diperlengkapi dengan beberapa orang tenaga administrasi. Di wilayah bekas Kerajaan Bone, pasukan Belanda pada mulanya ditempatkan di Watampone, Pompanua,Mare, dan Pattiro Bulu (Arsip Bone, No.5/2; Patunru, 1989: 286; Amir, 2003: 116).

Keadaan itu melapangkan Petta Barang lebih leluasa mengorganisir kekuatan di Pasempe, untuk menyerang kedudukan pemerintahan Belanda di Watampone. Penampilannya sebagai dukun sakti dan pemberian jimat kekebalan kepada pengikutnya, ia berhasil memperoleh pengikut yang banyak. Para pengikutnya yakin mereka kebal terhadap senjata berkat jimat itu sehingga membangkitkan keberanian dan semangat perjuangan. Setelah 
segala persiapan dirampungkan, ia mengorganisir pengikutnya untuk melancarkan serangan. Dengan bersenjatakan tombak dan keris atau badik, mereka berangkat menuju Watampone pada pertengahan Juli 1906. Sasaran penyerangan adalah bivak (perkemahan darurat militer) pasukan Belanda di Watampone. Ketika menjelang dini hari, para pengikut Petta Barang melancarkan serangan secara tidak terduga, sehingga pasukan Belanda tidak berhasil mengorganisir kekuatan dalam menghadapi serangan musuh. Setelah melancarkan serangan, mereka dengan segera meninggalkan tempat kejadian (Kolonial Verslag, 1907: 60).

Para penyerang meninggalkan tempat itu dengan meneriakkan bahwa akan kembali lagi menyerang di bawah pimpinan Petta Barang. Pernyataan itu membuat anggota pasukan Belanda senantiasa bersiaga dan melakukan patroli untuk mencegah rencana penyerangan. Sementara penduduk dicekam ketakutan dan kecemasan akan terjadinya penyerangan susulan. Keadaan itu tidak hanya mewarnai kota Watampone, tetapi juga di tempat pasukan Belanda berada. Karena itu Gubernur Swart menyatakan bahwa gangguan keamanan dan ketentraman di Bone masih terus berlangsung hingga akhir 1906. Hal itu disebabkan adanya berita yang terus disebarkan tentang akan terjadinya penyerangan susulan yang dipimpin oleh Petta Barang (Swart, 1908: MvO).

Petta Barang bersama para pengikunya setelah menyerang Watampone, tidak melakukan serangan lagi hingga permulaan 1907. Nampaknya penyebaran berita tentang penyerangan susulan merupakan tektik untuk mengundang pasukan Belanda melakukan patroli dan keadaan itu dimanfaatkan untuk melakukan serangan. Itulah sebabnya ketika satu regu pasukan patroli Belanda berada di Pising (Lamuru) pada 22 Februari 1907, tiga orang pengikut Petta Barang yang bersenjatakan tombak melancarkan serangan. Serangan yang dilancarkan secara tiba-tiba itu berakibat seorang prajurit Belanda meninggal, sementara kelompok penyerang gugur dua orang dan seorang berhasil menyelamatkan diri (Kolonial Verslag,1908: 89). Menurut Gubernur Swart, bahwa Petta Barang mulai lebih banyak melakukan penyerangan sejak Februari 1907. Penyerangan-penyerangan itu tidak dilakukan secara terbuka terhadap pasukan Belanda, sebab ia hanya memiliki beberapa pengikut yang bersenjata. Namun dengan membagi-bagikan jimat kepada penduduk, sehingga para pengikutnya semakin bertambah (Swart, 1908: MvO).
Selain melakukan penyerangan terhadap kedudukan Belanda di wilayah Bone, Petta Barang juga mengorganisasikan perlawanan di wilayah bekas kerajaan-kerajaan lain di Sulawesi Selatan. Di Tanete misalnya, pasukan patroli Belanda diserang pengikut Petta Barang yang dipimpin oleh Daeng Patompo pada 26 Juli 1907. Diperoleh berita bahwa Petta Barang selalu berada di Tanete. Karena itu pasukan Belanda melakukan penyerangan terhadap daerah itu dan Daeng Patompo gugur pada peristiwa itu. Pada akhir Juli 1907, pasukan Belanda kembali melakukan penyerangan terhadap Tanete, namun Petta Barang dapat meloloskan diri berkat bantuan dari pengikutnya yang terdekat. Selama Petta Barang berada di Tanete, ia senantiasa berada di bawah perlindungan dari La Tenri Sessu, Datu Bakke (Kolonial Verslag,1908: 91; Swart,1908: $\mathrm{MvO}$ ).

Penyerangan terhadap kedudukan pasukan Belanda di Parepare pada Oktober 1907, juga diperkirakan diorganisir oleh Petta Barang. Pada peristiwa itu, sekitar 30 orang melakukan penyerangan terhadap bivak pada dini hari 11 Oktober 1907. Peristiwa yang dilancarkan secara tiba-tiba itu mengakibatkan seorang wanita meninggal serta tiga orang laki-laki dan seorang wanita menderita luka-luka. Meskipun para penyerang langsung melarikan diri setelah penyerangan itu, namun pihak pasukan Belanda berhasil menyerang balik yang mengakibatkan tiga orang gugur (Kolonial Verslag,1908: 92). Selain itu, para pengikut Petta Barang juga melancarkan serangan sekali lagi terhadap bivak di Watampone pada akhir Oktober 1907. Korban akibat serangan itu tidak diberitakan. Meskipun kelompok penyerang segera melarikan diri setelah melancarkan serangan, namun sebagian dari mereka berhasil ditawan oleh pasukan Belanda berkat kerja sama dengan kepala kampung dan rakyat (Swart,1908: MvO; Poelinggomang \& Muh. Arfah, 1995: 61).

Jika diperhatikan taktik dan starategi penyerangan pengikut Petta Barang tersebut, maka tampak bahwa gerakan itu bercorak gangguan keamanan dan ketertiban. Taktik yang digunakan setelah malancarkan serangan, adalah segera meninggalkan lokasi dan memperdengarkan berita bahwa akan ada lagi penyerangan susulan. Dengan cara itu mereka mengundang kecemasan penduduk dan mendorong pasukan Belanda untuk malaksanakan patroli. Melalui taktik ini, Petta Barang berusaha untuk mendapatkan keuntungkan bagi gerakannya. Sementara penduduk yang merasa 
cemas dan ketakutan dengan berita penyerangan susulan, diharapkan mereka berpikir bahwa kelompok perlawanan Petta Barang termasuk kelompok yang kuat dan beranggotakan para pemberani. Sebab jika tidak demikian, mereka pasti tidak berani mengumumkan rencana penyerangan berikutnya.

Taktik perlawanan tersebut, juga dimaksudkan agar penduduk tidak berani menentang para pengikut Petta Barang, bahkan sebaliknya memberikan kemudahan dan fasilitas agar terhindar dari ancaman. Di samping itu, juga dapat mempengaruhi penduduk untuk ikut menjadi pengikut Petta Barang. Selanjutnya, dengan rangsangan pemberian jimat yang dapat memberikan kepada pemakainya kekebalan terhadap senjata, dapat dipastikan bahwa Petta Barang semakin bertambah pengikutnya. Terlebih lagi Petta Barang bersama para pengikutnya, juga mendapat fasilitas pemondokan dan pangan dari bagsawan-bangsawan dan para penguasa lokal yang mendukung dan membantu perjuangannya dalam menentang kekuasaan Belanda.

Maksud lain dari pemberitaan penyerangan susulan tersebut, juga bertujuan mengundang pasukan Belanda melakukan patroli. Pasukan patroli umumnya berjumlah kecil, biasanya satu regu. Jumlah pasukan yang kecil itu akan lebih memungkinkan para pengikut Petta Barang yang hanya bersenjatakan tombak dan keris lebih berani dan berhasil menyerang. Serangan-serangan itu juga sekaligus merupakan demontrasi keberanian dan kehebatan pengikut-pengikut Petta Barang. Laporan-laporan pemerintah Belanda menyangkut kegiatan Petta Barang pada 1907, menunjukkan bahwa serangn lebih banyak dilakukan terhadap pasukan patroli secara tiba-tiba, kemudian segera lari meninggalkan lokasi penyerangan. Keberanian yang tampilkan dan didemontrasikan para pengikut Petta Barang pada gilirannya juga menggugah penduduk mengagumi pemimpin mereka. Hal itu bukan hanya memudahkan penduduk menerima mitologi yang ditampilkan untuk melegitimasikan kedudukan kepemimpinan Petta Barang, melainkan juga menerimanya sebagai seorang pemimpin gerakan perlawanan yang memiliki kesaktian dan menguasai kekuatan supernatural.

Petta Pabarang sebagai pimpinan gerakan, belum berhasil ditangkap dan ditawan hingga akhir 1907. Setiap usaha penyerangan terhadap tokoh itu selalu gagal, sebab ia senantiasa dapat meloloskan diri dari sergapan pasukan Belanda.
Keberhasilannya dalam meloloskan diri setiap usaha penyergapan, semakin menimbulkan ketenaran di kalangan pengikut dan penduduk. Timbul anggapan bahwa tokoh itu cepat menghilang apabila hendak ditangkap. Juga dikisahkan bahwa ia sering berganti wajah, sebentar kelihatan bagaikan seorang yang sudah tua, dan kadang-kadang tampak bagaikan seorang pemuda yang gagah dan tampan. Kesemuanya itu bukan hanya mengandung kekaguman yang merangsang orang untuk berguru dan menjadi pengikutnya, melainkan juga membuat kegelisahan dan ketakutan di kalangan penduduk (Transkrip No.5 dan Transkrip No.22).

Pada Januari 1908, tersebar berita Petta Barang akan melancarkan serangan terhadap bivak di Pattiro Bulu. Berita itu mendorong pemerintah Belanda mengirimkan dua brigade polisi militer (marechaussees) ke Pattiro Bulu. Pengiriman pasukan itu dilakukan secara rahasia, tanpa diketahui oleh pengikut Petta Barang. Berita itu menjadi kenyataan ketika para pengikut Petta Barang melancarkan serangan terhadap bivak di Pattiro Bulu pada awal Februari 1908. Serangan yang dilancarkan dengan jumlah anggota yang cukup banyak dengan bersenjatakan tombak dan keris itu berhasil dikalahkan oleh pasukan Belanda yang telah dipersiapkan sebelumnya. Bahkan pasukan Belanda berhasil melancarkan serangan balik terhadap kelompok penyerang yang berusaha melarikan diri. Pada peristiwa itu, 39 orang pengikut Petta Barang gugur dan luka-luka tidak diketahui. Selain itu, juga beberapa orang pengikut Petta Barang berhasil ditangkap dan ditawan oleh pasukan Belanda (Kolonial Verslag, 1908: 92; Poelinggomang \& Muh. Arfah, 1995: 65).

Kegagalan itu mempunyai dampak terhadap kesetiaan para pengikut Petta Barang. Sebab tidak lama setelah peristiwa itu, Karaeng Bado, salah seorang pemimpin penyerangan bivak Pattiro Bulu, menyerahkan diri kepada pasukan Belanda. Karaeng Bado selanjutnya diajukan ke pengadilan negeri dan dijatuhi hukuman 15 tahun penjara. Selain itu, juga karena terjalin kerjasama yang baik antara para pemimpin rakyat dan penduduk dengan pasukan Belanda dalam usaha pengejaran, sehingga semakin menyulitkan pergerakan Petta Barang bersama para pengikutnya. Terlebih setelah paman, istri, dan saudara perempuan Petta Barang ditangkap oleh pemerintah kolonial. Akibatnya kedudukan kepemimpinannya semakin merosot, bahkan di kalangan para pengikutnya berkembang pemikiran yang meragukan kedudukan Petta Barang sebagai 
tokoh yang memiliki kesaktian, seorang pemimpin yang diturunkan dari langit untuk membebaskan rakyat dari kekuasaan Belanda. Oleh karena itu, lambat laun pengikutnya semakin berkurang serta dukungan dan bantuan yang diperoleh semakin sedikit (Poelinggomang \& Muh. Arfah, 1995: 66).

Meskipun demikian, tidak memudarkan semangat perjuangan Petta Barang. Ia berusaha menjalin hubungan dengan Andi Panambong di Soppeng (Rasyid, 2007: 47). Menurut laporan Gubernur Coenen, bahwa Andi Panambong adalah seorang pemimpin bandit terkenal di Soppeng. Ia mengorganisir empat kelompok perampok di Soppeng. Kerjasama yang dibina itu memberikan keuntungan bagi kegiatan mereka. Mereka berdua mendapat dukungan dan bantuan dari kebanyakan bangsawan di Soppeng dan Bone (Coenen,1913: $\mathrm{MvO}$ ). Namun berita tentang kegiatan penyerangannya tidak terdengar lagi. Beberapa penyerangan terhadap pasukan patroli Belanda yang menggunakan taktik yang sama dengan yang digunakan oleh para pengikut Petta Barang, menggundang interpensi dari pejabat pemerintah Belanda untuk menyatakan bahwa gerakan itu dilakukan oleh pengikut Petta Barang (Kolonial Verslag, 1912: 46).

Salah satu di antaranya adalah gerakan yang dipimpin oleh Nyimpa di daerah perbatasan Bone Selatan dan Sinjai. Nyimpa mengorganisir penduduk Kampung Lohe Batu untuk menyerang pejabat pemerintah yang ditempatkan di Bikeru pada $1909 .{ }^{12}$ Gerakan yang dianggap didalangi oleh pengikut Petta Barang ini dengan mudah dapat dipadamkan oleh pasukan Belanda yang ditempatkan di Onderafdeeling Zuid Bone. Demikian pula halnya dengan gerakan kerohanian yang dipimpin oleh Ambo Sida di Kampung Lapajung (Onderafdeling Soppeng) pada Juni 1911. Pada umumnya setiap gerakan yang diarahkan pada rencana ataupun penyerangan terhadap pasukan patroli Belanda dan bivak pasukan Belanda yang terjadi di Tanete, Soppeng, Wajo, Bone, Sinjai, Segeri, dan beberapa daerah yang dihuni oleh etnis Bugis lainnya dikaitkan dengan gerakan kerohanian

12 Bikeru merupakan tempat di mana Petta Barang menetap semasa hidupnya. Itulah sebabnya gerakan yang terjadi itu dipandang dilakukan oleh pengikut Petta Barang, di samping corak gerakan yang sama dengan gerakan Petta Barang. Gerakan itu diawali dengan penolakan penduduk untuk disensus dan membayar pajak. yang dipimpin oleh Petta Barang. Bahkan gerakan Petta Barang masih disebut-sebut sebagai ancaman terhadap keamanan dan ketertiban bagi pemerintah Belanda hingga 1941 (Harvey, 1989: 52).

\section{Penumpasan Gerakan Petta Barang}

Pada awal gerakan Petta Barang, pemerintah Belanda belum bergiat sepenuhnya untuk menangkap tokoh pemimpin gerakan itu. Mereka hanya bergiat mengadakan pengawasan keamanan dengan pasukan patroli. Hal itu berkaitan erat dengan kondisional saatitu. Jumlah pasukan Belanda yang tersedia terbatas untuk dapat menjamin keamanan dan ketertiban di wilayah Gouvenement Celebes en Onderhoorigheden. Sementara keadaan di wilayah ini tidak memungkinkan pemusatan kekuatan untuk menumpas gerakan perlawanan yang bercorak kerohanian yang demikian banyak. Demikian juga terhadap gangguan keamanan akibat kelompok perampok, baik karena tekanan ekonomi maupun sebagai gerakan protes sosial dan politik. Itulah sebabnya Gubernur Swart lebih banyak memusatkan perhatian pada pengawasan keamanan dan ketertiban dan kurang memusatkan perhatian pada penumpasan gerakan perlawanan atau gerakan pengacauan dan tindakan-tindakan yang bertentangan dengan peraturan dan hukum yang berlaku (Swart, 1908: MvO).

Namun ketika Petta Barang melakukan penyerangan terhadap bivak di Pattiro Bulu pada Februari 1908, pemerintah Belanda mulai melangkah untuk bergit menumpas gerakan itu. Untuk itu diperintahkan kepada Lettu Pimentel memimpin satu pasukan mengadakan patroli dalam rangka mengikuti, mengawasi, dan menangkap tokoh gerakan itu. Hal itu menunjukkan bahwa pemerintah Belanda masih meragukan apakah setiap gerakan penyerangan terhadap pasukan patroli dan bivak itu diorganisir oleh Petta Barang. Hasil penelitian Pimentel membuktikan bahwa memang benar gerakan itu diorganisir dan dipimpin oleh Petta Barang. Oleh karena itu, dilakukan usaha pengejaran terhadap Petta Barang yang sedang berada di Barru. Pada 2 April 1908, pasukan patroli khusus yang dipimpin oleh Pimentel melancarkan serangan terhadap Petta Barang. Pada peristiwa itu lima orang pengikutnya gugur, namun Petta Barang berhasil meloloskan diri. Karena itu usaha pengejaran terus dilakukan di Barru dan Soppeng, yang dipandang sebagai tempat persembunyian Petta Barang bersama para pengikutnya (Poelinggomang \& Muh. Arfah,1995: 67). 
Pada waktu Gubernur Sulawesi A. J. Baron Quarles de Quarles (Mei 1908-Agustus 1910) tampil menggantikan Gubernur Swart, usaha untuk mengejar dan menangkap Petta Barang kurang mendapat perhatian. Sebab, menurutnya bahwa Petta Barang bukanlah seorang yang berbahaya. Karena itu usaha pengejaran secara khusus terhadapnya dihentikan. Hanya pasukanpasukan patroli yang berada di setiap tempat diharapkan waspada terus dan jika menemukan dilakukan pengejaran dan menangkap, bukan hanya Petta Barang melainkan juga para pemimpin gerakan kerohanian dan gerakan perbanditan lainnya. Sementara perhatian yang diutamakan adalah perbaikan kehidupan ekonomi dan sosial serta penataan wilayah pemerintahan, misalnya, perbaikan jalan, jembatan, dan irigasi (Quarles, 1910: $\mathrm{MvO}$ ).

Pada dasarnya Quarles berpendapat bahwa melalui perbaikan penataan wilayah pemerintahan, sarana dan prasarana yang menunjang perbaikan kehidupan ekonomi, akan mampu mengatasi berbagai tantangan dan perlawanan yang diorganisir oleh pemimpin-pemimpin gerakan dan kegiatan-kegiatan yang bertentangan dengan hukum seperti perampokan. Apa yang dicanangkan oleh Quarles itu, berhasil mengatasi gangguan ketertiban dan keamanan yang terjadi di Sulawesi Selatan pada umumnya dan Bone pada khususnya. Perbaikan pemerintahan, kehidupan ekonomi, dan sosial berhasil memikat jalinan kerjasama yang baik antara para pemimpin rakyat dan masyarakat dengan pemerintah Belanda (Quarles, 1910: MvO).

Jalinan kerjasama yang melibatkan para pemimpin rakyat dan masyarakat tersebut, tidak hanya ikut bekerja memperbaiki sarana dan prasarana kehidupan, tetapi juga memberi bantuan dalam usaha menjamin keamanan dan ketertiban. Arung Cenrana bersama patroli penduduk telah membantu pemerintah Belanda membinasakan kelompok perampok yang dipimpin La Matto, seorang narapidana yang melarikan diri dari penjara Watampone dan mengorganisir perampokan di Cenrana dan Sailong. Penyerangan yang dilancarkan penduduk di bawah pimpinan Arung Cenrana pada November 1909, berhasil membinasakan La Matto bersama seorang pengawalnya serta menawan empat orang pengikutnya. Selain itu, juga berkat kerjasama sehingga setiap persiapan gerakan rakyat dengan mudah dapat dipadamkan sebelum meletus, karena dengan segera dilaporkan kepada pemerintah Belanda, misalnya gerakan Matoa
Baringeng pada September 1910 (Poelinggomang \& Muh. Arfah,1995: 70)..$^{13}$

Ketika W.J. Coenen menjadi gubernur Sulawesi (Agustus 1910 - Oktober 1913), usaha mengatasi berbagai gerakan perlawanan dan gangguan keamanan kembali menjadi perhatian penting dan diarahkan pada tindakan militer. Demikian pula halnya dengan gerakan Petta Barang, sebab menurutnya ia merupakan seorang tokoh yang berbahaya. Petta Barang memiliki pengaruh yang sangat luas dalam kalangan masyarakat Bugis dan Makassar, baik dalam lingkungan bangsawan tinggi, kepala-kepala kampung maupun masyarakat umum. Ia merupakan seorang tokoh yang berwibawa, dan oleh masyarakat dipandang sebagai seorang tomanurung. Karena itu, menurut Coenen gerakan itu harus dibinasakan dengan kekuatan militer. Ia memerintahkan dilakukan patroli militer khusus untuk mengejar dan menangkap Petta Barang (Coenen,1913: MvO).

Pengejaran yang dilakukan oleh pasukan Belanda itu menyebabkan kedudukan Petta Barang semakin terdesak. Dalam keadan itu, ia akhirnya berusaha menggabungkan diri dengan kelompok Andi Panambong, yang selama itu mengorganisir kegiatan perampokan di Soppeng. Penggabungan itu memberikan dorongan keberanian kepada para pengikut Andi Panambong untuk melaksanakan perampokan secara terang-terangan. Namun kegiatan perampokan itu memudahkan bagi

13 Peristiwa itu bermula ketika Matoa Baringeng berhasil mengambil arajang Lamuru pada waktu Datu Lamuru diturunkan oleh pasukan Belanda. Arajang itu kemudian disembunyikan di rumah salah seorang anak dari Madanrang Petojo. Setelah terbentuk pemerintahan baru di Lamuru, penguasa Lamuru meminta agar Matoa Baringeng menyerahkan arajang itu kembali kepada pemerintah. Permintaan itu ditolak oleh Matoa Baringeng dan berkat hasutan dari Madanrang Petojo, arajang itu dipertahankan dan berusaha memindahkannya ke Kampung Enrekang (Lamuru). Meskipun demikian, para kepala kampung dari Lamuru berhasil mengambil kembali arajang itu di Enrekang dan menyerahkan kembali kepada pemerintah. Karena itu, Matoa Baringeng dan Madanrang Petojo merencanakan penyerangan terhadap pemerintah Belanda di Lamuru. Peristiwa itu dapat dipadamkan berkat kerjasama antara pemerintah Belanda dengan para kepala kampung dan rakyat. Bahkan peristiwa itu dalam waktu singkat dengan mudah dapat diselesaikan, tanpa terjadi korban harta dan jiwa berkat kerjasama yang telah terjalin antara pemerintah kolonial Belanda dengan para pemimpin atau kepala-kepala kampung. 
pasukan Belanda, sebab dengan mudah dapat mengetahui tempat persembunyian Petta Barang dan Andi Panambong. Oleh karena itu pasukan Belanda melancarkan serangan terhadap tempat persembunyian Petta Barang dan Andi Panambong di wilayah Onderafdeling Soppeng pada 30 Agustus 1912. Dalam penyerangan itu Petta Barang berhasil meloloskan diri, namun Andi Panambong sendiri gugur bersama beberapa orang pengikutnya (Rasyid,2007: 48).

Kematian Andi Panambong itu berakibat Petta Barang kehilangan dukungan dalam melanjutkan perlawanan. Ia selanjutnya mengungsikan diri ke hulu Sungai Walimpung. Di tempat persembunyian itu, sekali lagi diserang oleh pasukan Belanda. Dalam penyerangan itu, ia juga berhasil meloloskan diri. Pada Mei 1913, Datu Citta berhasil mengetahui tempat persembunyian Petta Barang. Datu Citta selanjutnya mengorganisir patroli rakyat yang langsung di bawah pimpinannya untuk mengejar dan menangkap Petta Barang. Ia terlebih dahulu memisahkan Petta Barang dari para pengikutnya. Oleh karena itu, Datu Citta berhasil menangkap Petta Barang di tempat persembunyiannya di Ale Cinto (Onderafdeling Soppeng) pada 5 Mei 1913. Selanjutnya Datu Citta mengantar Petta Barang ke Watan Soppeng dan menyerahkannya kepada pejabat Civiele Gezaghebber (Coenen, 1913: MvO; Poelinggomang \& Muh. Arfah, 1995: 75; Transkrip No.7).

Petta Barang selanjutnya diajukan ke pengadilan Bumiputra (inheemsche rectbank) di Watan Soppeng. Ia dinyatakan bersalah melakukan komplotan untuk menjatuhkan pemerintahan Belanda. Karena itu, pengadilan memutuskan dan menjatuhkan hukuman 20 tahun penjara (Surat Keputusan Pengadilan Bumiputra Watan Soppeng Tanggal 15 Mei 1913 No.11). Setelah dijatuhi hukman, Petta Barang selanjutnya dibawa ke Makassar untuk dipenjarakan. Namun, Gubernur Coenen yang sejak awal memandang Petta Barang sebagai tokoh yang berbahaya, merasa kuatir jika dipenjarakan di Makassar. Sebab ia tidak mempercayai sepenuhnya pengawasan petugas penjara terhadap Petta Barang. Coenen kuatir kelak Petta Barang dapat meloloskan diri dari penjara. Oleh karena itu diputuskan mengirim Petta Barang ke Batavia. Pada 7 Juni 1913, Daeng Pabarang diberangkatkan ke Jawa. Sementara menanti keputusan penentuan tempat pengasingannya, Petta Barang akhirnya meninggal sebagai seorang tawanan dalam penjara (Coenen,1913: MvO).
Namun sebagai masyarakat di daerah Bugis tidak percaya tentang kematian itu, terutama di kalangan pengikut dan keturunannya.

\section{PENUTUP}

Gerakan Petta Barang bukan hanya dilatarbelakangi oleh pendudukan militer dan penghapusan sistem kerajaan, melainkan juga oleh keresahan masyarakat akibat terjadinya peubahan sosial sebagai konsekuensi semakin kuatnya pengaruh kekuasaan Belanda di Bone. Pengambilalihankekuasaan melalui ekspedisi militer Belanda, mengakibatkan sejumlah bangsawan kehilangan sumber pendapatan dan kekuasaan mereka. Oleh karena itu, kepentingan ekonomi dan politik merupakan faktor penting munculnya gerakan Petta Barang. Sementara perubahan sosial yang menyertai penghapusan sistem kerajaan dan pelaksanaan sistem pemerintahan kolonial Belanda, seperti wajib pajak dan kerja rodi, telah menimbulkan keresahan masyarakat. Itulah sebabnya gerakan Petta Barang yang hendak mengusir penjajahan Belanda dan memulihkan kembali kedudukan kekuasaan Kerajaan Bone mudah mendapat dukungan dari masyarakat.

Dukungan terhadap gerakan Petta Barang, tidak terlepas dari taktik yang digunakan. Petta Barang mengawali gerakannya sebagai seorang dukun yang sakti dan "menjual" atau membagikan jimat kepada pasien atau penduduk yang bersedia menjadi pengikutnya. Berkat dukungan dan bantuan dari sejumlah bangsawan dan penduduk di daerah Bugis, Petta Barang semakin kuat kedudukan kekuasaannya. Itulah sebabnya ia berani memerintahkan kepada para pengikutnya untuk melancarkan serangan terhadap kedudukan pemerintah kolonial Belanda, bivak dan patroli pasukan Belanda. Taktik perlawanan yang dilakukan oleh Petta Barang bersama para pengikutnya cukup merepotkan pasukan Belanda sehingga dikerahkan pasukan khusus untuk menumpasnya. Setelah berukanglai mengalami kegagalan, pasukan Belanda akhirnya berhasil menangkap Petta Barang di Ale Cinto, Soppeng pada 5 Mei 1913. Petta Barang kemudian dijatuhi hukuman 20 tahun penjara. Dengan alasan keamanan dan ketertiban Petta Barang diasingkan ke Jawa, namun ia meninggal dalam penjara sebelum menjalani kehidupan yang menyengsarakan dalam pengasingan.

\section{UCAPAN TERIMA KASIH}

Penulis menghayurkan banyak terima kasih kepada semua pihak yang berkontribusi pada artikel 
ini, terutama terhadap almarhum Dr. Edward L. Poelinggomang, Drs. Muhammad Arfah, Andi Mappasissi, Andi Muhammad Ali, dan Taggala. Selain itu, juga terima kasih kepada Andi Ahmad serta pimpinan dan staf Arsip Nasional Republik Indonesia Jakarta, Badan Arsip dan Perpustakaan Provinsi Sulawesi Selatan, BPNB Makassar, serta pengelola Jurnal Al-Qalam yang telah memasukkan artikel ini sebagai bagian edisi ini.

\section{DAFTAR PUSTAKA}

Abduh, Muhammad, dkk. 1985. Sejarah Perjuangan Terhadap Imprlialisme dan Kolonialisme di Sulawesi Selatan. Jakarta: Dekdibdud.

Ahmad, Taupik. 2014. "Bandit dan Pejuang: Sejarah Sosial Politik Masyarakat Polongbangkeng (19051960-an)", dalam Jurnal Sejarah dan Budaya Walasuji. Makassar: Balai Pelestarian Nilai Budaya Makassar.

Ali, Andi Muh. 1984. Rumpa’na Bone (Perang Bone) 1905. Watampone: Damai.

Amir, Muhammad. 2003. Perlawanan Bone Terhadap Belanda Tahun 1905. Makassar: Era Media.

Anonim. 1905. "Gubeurtenissen bij het begin der Boniexpeditie door een ooggetuige; Uit mijn dagboek", dalam Boon's Geillustreerd Magazijn 7.

1905-1906. "De Gubeurtenissen in ZuidCelebes", dalam Weekblad voor Indie 2.

. 1915-1916. De Expeditie naar Zuid-Celebes in 1905-06, dalam Indisch Militair Tijdschrift, Extra Bijlage.

Arsip Bone, No.5/2. Koleksi Badan Arsip dan Perpustakaan Provinsi Sulawesi Selatan.

Caron, L. J. J. 1933. Memori van Overgave $(\mathrm{MvO})$ Gouvenement Celebes en Onderhoorigheden (Agustus 1929 - November 1933). Koleksi Arsip Edward L. Poelinggomang.

Coenen, W.J. 1913. Memori van Overgave $(\mathrm{MvO})$ Gouvenement Celebes en Onderhoorigheden (Oktober 1910 - Agustus 1913). Koleksi Arsip Edward L. Poelinggomang.

Couvreur, A. J. L. 1929. Memori van Overgave (Juni 1924-Juni 1929), dalam Koninklijk Instituut voor Taal, Land en Volkenkunde van NederlandscheIndie (KITLV), No. 71.

Gonggong, Anhar. 1992. Abdul Qahhar Mudzakkar Dari Patriot Hingga Pemberontak. Jakarta: Gramedia Widiasarana Indonesia.

Gottschalk, Louis. 1986. Mengerti Sejarah (Diterjemahkan Nugroho Noto-susanto). Jakarta: Universitas Indonesia Press.

Harvey, Barbara Sillars. 1989. Pemberontakan Kahar Muzakkar Dari Tradisi Ke DI/TII. Jakarta: Grafiti.
Kadir, Harun, dkk. 1984. Sejarah Perjuangan Kemerdekaan Republik Indonesia di Sulawesi Selatan 1945-1950. Ujung Pandang: Kerja Sama Bappeda Provinsi Sulawesi Selatan dengan Unhas.

Kielstra, E.B. 1910. Kumpulan Artikel, Koleksi Arsip dan Perpustakaan Provinsi Sulawesi Selatan.

Kolonial Verslag. 1907. Zuid Celebes, Medeelingeng van het Staatkundige en Algeeme Aart. . 1908. Zuid Celebes, Medeelingeng van het Staatkundige en Algeeme Aart. . 1912. Zuid Celebes, Medeelingeng van het Staatkundige en Algeeme Aart.

Kroesen, C. A. 1906. Memorie van Overgave van het Bestuur Over Het Gouvernement Celebes en Onderhoorigheden. Koleksi Arsip Nasional Republik Indonesia, Jakarta.

Mappangara, Suriadi. 1996. "Kerajaan Bone Abad XIX: Konflik Kerajaan Bone - Belanda 18161860". Yogyakarta: Tesis Program Pascasarjana Universitas Gadjah Mada.

Mattulada. 1998. Sejarah, Kebudayaan, dan Masyarakat Sulawesi Selatan. Makassar: Hasanuddin University Press.

Memori Betreffende. 1912. Memori Betreffende de Onderafdeeling Bone met Bijlagen (Opgemaath Ingevalge Schrijven van het Departemen van Oorlog VII Afdeling, 12 Agustus 1912, No.765).

Nabba, Andi Palloge Petta. 2006. Sejarah Kerajaan Tanah Bone. Makassar: Yayasan Al Muallim.

Notosusanto, Nugroho. 1978. Masalah Penelitian Sejarah Kontemporer. Jakarta: Idayu.

PaEni, Mukhlis, dkk. 2002. Batara Gowa Messianisme Dalam Gerakan Sosial di Makassar. Yogyakarta: Gadjah Mada Universtity Press.

Patang, Lahajdji. 1976. Sulawesi dan PahlawanPahlawannya. Jakarta: YKGMI.

Patunru, Abd. Razak Daeng. 1983. Sejarah Gowa. Ujung Pandang: Yayasan Kebudayaan Sulawesi Selatan.

Patunru, Abd. Razak Daeng. 1989. Sejarah Bone. Ujung Pandang: Yayasan Kebudayaan Sulawesi Selatan.

Pemda Bone. 1993. Selayang Pandang Kabupaten Dati II Bone. Watampone: Pemerintah Kabupaten Bone.

Poelinggomang, Edward L. \& Muh. Arfah. 1995. "Perlawanan Rakyat Pasca Ekspedisi Militer Belanda di Sulawesi Selatan Pada 1905". Ujung Pandang: Laporan Penelitian Bidang Jarahnitra Kanwil Depdikbud Provinsi Sulawesi Selatan. 1980. "Perlawanan Rakyat Gowa Terhadap Pendudukan Belanda Tahun 1905”. Yogyakarta: Skripsi Sarjan Universitas Gadjah Mada. 2002. Makassar Abad XIX: Studi Tentang Kebijakan Perdagangan Maritim. Jakarta: Kepstkaan Populer Gramedia (KPG). - 2004. Perubahan Politik \& Hubungan Kekuasaan Makassar 1906-1942. Yogyakarta: Ombak. 
2005. Sejarah Sulawesi Selatan. Makassar: Balibangsa Provinsi Sulawesi Selatan.

Quarles, A. J. Baron Quarles de. 1910. Memori van Overgave (MvO) Gouvenement Celebes en Onderhoorigheden (Mei 1908-Agustus 1910). Koleksi Arsip Edward L. Poelinggomang.

Rasyid, Darwas. 2007. "Gerakan Andi Panambong di Soppeng”. Makassar: Laporang Penelitian Balai Kajian Sejarah dan Nilai Tradisional.

Shahib, M. Roem. 1980. "Bone Kartu Mati Bagi Perjuangan Merah Putih di Sulawesi Selatan Pada Tahun 1945-1950". Ujung Pandang: Skripsi Sarjana Unhas.

Surat Keputusan Pengadilan Bumiputra Watan Soppeng Tertanggal 15 Mei 1913 No. 11.

Swart, H.N.A. 1908. Memori van Overgave (MvO) Gouvenement Celebes en Onderhoorigheden (September 1906-April 1908). Koleksi Arsip Edward L. Poelinggomang.

Tideman, J. 1908. "De Batara Gowa op Zuid Celebes", dalam Bijdragen tot de Taal, Land en Volkenkunde van Nederlandsche-Indie (BKI), No.64.
Tol, Roger. 2009. “Otoritas Tekstual Toloq Rumpaqna Bone; Oleh I Mallaq Daeng Mabela, Arung Manajeng", dalam Kuasa dan Usaha di Masyarakat Sulawesi Selatan. Makassar: Ininnawa bekerja sama dengan KITLV Jakarta.

Transkrip No. 19. Hasil Wawancara Andi Mappasissi di Watampone pada 7 Maret 1995. Koleksi Sejarah Lisan Bidang Jarahnitra Kanwil Provinsi Sulawesi Selatan.

Transkrip No. 2. Hasil Wawancara Andi Muh. Ali di Watampone pada 5 Februari 1992. Koleksi Sejarah Lisan Bidang Jarahnitra Kanwil Provinsi Sulawesi Selatan.

Transkrip No. 22. Hasil Wawancara Taggala di Pasempe pada 10 Maret 1995. Koleksi Sejarah Lisan Bidang Jarahnitra Kanwil Provinsi Sulawesi Selatan.

Transkrip No. 5. Hasil Wawancara Andi Mappasissi di Watampone pada 6 Februari 1992. Koleksi Sejarah Lisan Bidang Jarahnitra Kanwil Provinsi Sulawesi Selatan.

Transkrip No. 7. Hasil Wawancara Andi Ahmad di Citta, Soppeng pada 8 Mei 2017. 